\title{
Implementation of Sustainable Bioeconomy in European Union Countries: The Decomposition Analysis Approach
}

Genovaite Liobikiene ( $\nabla$ genovaite.liobikiene@vdu.It)

Vytautas Magnus University Agriculture Academy

Ričardas Krikštolaitis

Vytautas Magnus University

Astrida Miceikienè

Vytautas Magnus University Agriculture Academy

\section{Research Article}

Keywords: sustainable bioeconomy, efficiency, biomass, economic growth, decomposition analysis, European Union.

Posted Date: May 24th, 2021

DOI: https://doi.org/10.21203/rs.3.rs-432152/v1

License: (c) (i) This work is licensed under a Creative Commons Attribution 4.0 International License. Read Full License 


\section{Abstract}

Sustainability is highlighted in renewed European Union (EU) bioeconomy strategy. Sustainable bioeconomy requires improvement in the productivity level of bioresources, which is included in almost all national bioeconomy strategies. Therefore, the aim of this paper is to reveal how productivity (or conversely, intensity) level contributes to the changes in biomass extraction in all EU countries. Applying the IPAT approach, the results showed that in separate EU countries and analyzed periods, the changes in biomass extraction were different. During the period of economic growth (2000-2007) and transition (2008-2012), biomass extraction decreased in more than half of all EU countries. The decline of value added in the agriculture sector and/or reduction in biomass intensity level were the main determinants of these changes. Meanwhile, during the bioeconomy strategy period (2013-2018), the reduction of biomass extractions was observed in only 6 EU countries. During this period it was only in Greece, Italy and Malta that the productivity level of biomass offset the driving forces: economic and population growth. Meanwhile, in Estonia, Germany and Poland, despite the reduction of value added in the agriculture sector, the growth of the intensity level of biomass determined the increase in extraction of biomass. Therefore, this study showed that achievement of sustainable bioeconomy principles in the majority of EU countries remains a great challenge, and countries should make all efforts to enhance the productivity level of biomass.

\section{Introduction:}

The first bioeconomy strategy, "Innovating for sustainable growth: A bioeconomy for Europe" was presented in 2012 (EU, 2012). Despite the emphasis of sustainable growth, the environmental aspects of a sustainable supply of bioresource was insufficiently addressed there (European Bioeconomy Panel, 2014; Pfau et al., 2014). Thus, in recent years the concept of a "sustainable bioeconomy" has emerged (Koukios et al., 2018). In the literature, authors have vastly discussed and analyzed the tendencies of a sustainable bioeconomy (Hansen and Bjørkhaug 2017; Muizniece et al., 2016; Cristóbal et al., 2016; Scarlat et al., 2015; Blumberga et al. 2017; Sasson and Malpica, 2018; Juerges and Hansjürgens, 2018; Antas et al., 2021). A sustainable bioeconomy covers the efficient production of feed, food, biobased products and bioenergy products using renewable biological resources. Furthermore, Liobikiene et al. (2020) stated that by focusing on planetary boundaries, the concept of strong sustainability could be implemented. In the renewed bioeconomy strategy $(E U, 2018)$ the sustainable development aspect was particularly highlighted (EU, 2018) and maximized the contribution towards achieving the 2030 Agenda and Sustainable Development Goals.

A large number of authors have analyzed the role of bioeconomy seeking sustainable development goals (Ramcilovic-Suominen ans Pülzl, 2018; El-Chichakli et al., 2016; Sadhukhan et al., 2018; Ronzon ans Sanjuán, 2020; Zeug et I., 2019; Wohlafhrt et al., 2019; Giampietro, 2019; Egenolf and Bringezu, 2019; Urmetzer et al., 2020; Özgül and Bogdanski, 2021). Heimann et al. (2019) stated that bioeconomy implementation has the potential to jeopardize the accomplishment of sustainable development. However, when implementing the renewed bioeconomy strategy, not all targets of Sustainable 
Development Goals are achieved (Heimann, 2019; Ronzon ans Sanjuán, 2020). Consumption of bioresources is a major concern (Ronzon ans Sanjuán, 2020). Due to the fast development of the bioeconomy, the use of bioresources was expected to increase (Vainio et al., 2019) and until 2050 the demand could increase by nearly 50 \% (Piotrowski et al. 2015; Bell et al., 2018) which would enhance the pressure on the land (Kalt et al., 2016; Liobikiene et al., 2020). Therefore, the implementation of all sustainable development goals requires more than technical solutions (Ronzon ans Sanjuán, 2020).

The main condition to implementing a sustainable bioeconomy and Sustainable Development Goals is the interaction of socio-economic and environmental aspects. The efficiency (or productivity) level perfectly reflects this interaction and reveals the achievement of Sustainable Development Goals (ElChichakli et al., 2016). Therefore, bioresource productivity is particularly important in implementing a sustainable bioeconomy strategy (Scheiterle et al., 2017; Egelyng et al., 2017; Davaney and Henchion, 2018; Schutte, 2018; Zabaniotou, 2018). In achieving the bioresource efficient EU bioeconomy strategy, the circular bioeconomy concept is considered as well (Stegmann et al., 2020; Kardung et al., 2021; Sharma et al., 2021). However, the current productivity level is still incompatible with circular and sustainable bioeconomy (Giampietro, 2019; Angouria-Tsorochidou et al., 2021)

The role of enhancement of productivity levels is that the consumption (or production) of bioresource increases at a slower rate than economy, or better - decrease. In order to reveal whether the changes in productivity level offsets the changes in driving forces as population and economy activities, the IPAT (Impact x Population X Affluent $x$ Technology) approach is applied most often. This approach reveals how population, affluence (or economic development) and technologies contribute to changes in bioresources. This method was vastly applied when analyzing the carbon emissions or energy consumption. The IPAT approach was applied to analyze the determinants of material use as well (Schandl and West, 2012; Wang et al., 2014; Weinzettel and Kovanda, 2011; Huang et al., 2017; Chiu et al., 2017; Steinberger and Krausmann, 2011; West and Schandl, 2013; Fishman et al., 2015; Dong et al., 2017; Tian et al., 2017; Wang et al., 2013; Shah et al., 2020; Baninla et al. 2020). However, to the best of our knowledge, this analysis was not applied to examine the determinants of biomass extraction. The IPAT approach could present whether the enhancement of technologies (or of productivity level) offsets the economy and population growth. Therefore, by applying the IPAT approach, the aim of this paper was to reveal how productivity (or conversely intensity) level contributes to the changes in biomass extraction in all EU countries. It is a new topic on bioeconomy studies and could contribute to the improvement of sustainable bioeconomy strategy.

\section{Literature Review}

\subsection{Development of bioeconomy in EU countries}

The renewed bioeconomy strategy in all EU was launched in 2018. The adoption of this strategy is different in each EU country. With growing knowledge and awareness of the finite nature of fossil resources, and the growing climate, environmental, socio-economic and geopolitical impacts of their 
exploitation and use, along with their associated risks, the EU and many individual European and other countries have or are currently developing bioeconomy strategies. Until 2020 less than half of all EU countries (Spain, France, Germany, Italy, Latvia, United Kingdom, Austria, Finland, Ireland, the Netherland) have adopted a bioeconomy strategy at the national level. In the residual EU countries, this strategy is under development, or countries have developed other bioeconomy related initiatives.

The EU Bioeconomy Strategy emphasizes that the major opportunity and challenge is sustainable bioeconomy that requires various ecosystem and technological solutions, strategic policies, investments and policies that reward stakeholder innovation, including social entrepreneurship. The European Commission (2019) actively supported and promoted all types of innovations and practices for forestry and bio-based production, sustainable food and farming systems, through a systemic and cross-cutting approach linking actors, territories and value chains. The recent unprecedented COVID-19 crisis has brought to the surface a much wider role that the bioeconomy can have in diversifying supplies for food, feed, and raw materials, contributing to circularity and climate neutrality, whilst at the same time, creating employment and fostering rural development. New perspectives are needed to foster resilience and smooth the transition to a circular post-COVID-19 economy within the framework of the European Green Deal and the European Recovery Plan, in line with the EU Bioeconomy Strategy objectives. This implies embracing a transformative logic focused on turning the current challenges for local economic resilience into opportunities for diversification through deploying the bioeconomy widely.

Therefore, the successful implementation of sustainable bioeconomy strategy concerns all EU countries. Authors analyzing how countries implement bioeconomy strategy and the potential of bioeconomy development instead one country encompassed all EU countries. A large number of authors explored socioeconomic indicators, such as: output and employment multipliers of the bioeconomy sector, competitiveness effects and the differences among EU countries (Ronzon and M'Barek, 2018; Philippidis and Sanjuán-López, 2019; Fuenter-Saguar, 2017; Asada and Stern, 2018). Other authors (see: Hamelin et al., 2019; Withcchel et al., 2019; Mola-Yudego et al., 2019) encompassing all EU countries analyzed the residual biomass potential or potential of agricultural residues and wood biomass potentials for energy. Schipfer et al (2017) revealed the biomaterials scenarios for EU-28 countries up to 2050 and respective biomass demand. Scarlat et al (2018a.b) and Banja et al (2019) analyzed the biogas development and potential form manure in separate EU countries. Banja et al (2019) explored the biomass, Bórawski et al (2019) - biofuels supply for the energy sector in separate EU countries. Liobikiene at al. (2020) showed that the level of land footprint, biocapacity and possibilities of bioeconomy development vary across the EU countries. However, to the best of our knowledge, none of research analyzed the tendencies of sustainable bioeconomy implementation in all EU countries, considering the changes in biomass extraction and the main determinant in applying the IPAT approach.

\subsection{Efficiency of bioresource and the IPAT approach}

Biomass renewable sources are not "freely" available (as opposed to wind and water) and have a long supply chain from planting, growing, harvesting, pre-treatment, and conversion (Rural Biomass Energy 
Book, 2020). Authors have acknowledged that the implementation of sustainable bioeconomy requires improvements in the productivity (or efficiency) of the bioresources (Koukios et al., 2017; Scheiterle et al., 2017; Bell et al., 2018), in almost all national bioeconomy strategies. In the literature, authors analyzed only the level of productivity. Brizga et al (2019) revealed that in Baltic Sea Region countries from 2011 to 2015 , the productivity of bioresource changed differently. In Poland, productivity levels increased by $20 \%$. Meanwhile, in Finland, only by 0.3 \% (Brizga et al., 2020). Liobikienè et al (2020) showed that considering bioeconomy sector, the land footprint productivity in EU countries differed as well. Therefore, the big challenge remains for policymakers in how to enhance the productivity level. However, it is not only enough to enhance the level of bioresource productivity. The evaluation on how productivity levels contribute to the changes in bioresource extraction is necessary to analyze as well. To the best of our knowledge, this aspect was not analyzed by previous researchers. In order to reveal how productivity level contribute changes in bioresource extraction, the IPAT approach is suggested.

The IPAT analysis was proposed in the 1970s by Ehrich and widely used to analyze the drivers for energy use, environmental pollution, resource consumption and efficiency (Steinberger and Krausmann, 2011; Schandl and West, 2012; West and Schandl, 2013; Fishman et al., 2015; Tian et al., 2017; Dong et al., 2017; Chiu et al., 2017; Roman-Collado et al., 2018). Therefore, this method is suitable to analyze the drivers of bioresource extraction as well. IPAT decomposition analysis reveals the contribution of changes in population $(P)$, affluence $(A)$ and technology $(T)$ (or intensity level) to the changes in bioresource extraction. Tian et al (2017) stated that IPAT decomposition analysis encompasses two aspects of Environmental Kuznets Curve: scale (the population and economic growth) and technique effects, in our case - the reduction of bioresource intensity. Therefore, IPAT analysis shows whether the technologies or efficient enhancement offset the main driving forces of biomass extraction as population and economic growth (Fishman et al., 2015). Furthermore, this analysis is suitable for comparison analysis among countries and could contribute to a basis to spur mutual communication and cooperation among EU countries on the governance of sustainable bioresource extraction and improve the efficiency level (Baninla et al., 2020).

\section{Methods And Materials}

The purpose of this decomposition analysis is to identify and analyze how the changes in biomass domestic extraction $(B / O)$ have been brought about by changes in several independent factors. In this study, additive and multiplicative forms of index decomposition analysis were used to generate results from different perspectives and to enhance analysis and discussions. The multiplicative form illustrates the relative aspect for each factor in driving the changes in biomass domestic extraction, as the additive form provides a measure of the magnitude of changes in biomass extraction driven by decomposed factors.

In this paper, applying decomposition analysis, national BIO as an extended Kaya identity (Kaya, 1989) was expressed by the product of three factors: 


$$
B I O=P O P \cdot\left(\frac{V A A g r}{P O P}\right) \cdot\left(\frac{B I O}{V A A g r}\right)
$$

where $B I O$ is total domestic extraction of biomass in thousand tons, $P O P$ represents the total national population, VAAgr is total value added in agriculture in million EUR expressed in constant price. Ratio VAAgr/ POP means value added in agriculture sector per capita and ratio BIO/VAAgr means intensity of bioresources.

In multiplicative decomposition, the relative change of aggregate $B / O$ between year 0 (2000) and year $t$ was decomposed by the ratio of each factor, as shown in equation (2):

$$
B I O_{t}^{*}=P O P_{t}^{*} \cdot\left(\frac{V A A g r_{t}^{*}}{P O P_{t}^{*}}\right) \cdot\left(\frac{B I O_{t}^{*}}{V A A g r_{t}^{*}}\right),
$$

where $B I O_{t}^{*}=B I O_{t} / B I O_{0}, P O P_{t}^{*}=P O P_{t} / P O P_{0}, V A A g r_{t}^{*}=V A A g r_{t} / V A A g r_{0}$.

In additive decomposition, the absolute change in $B I O$ between year 0 (2000) and year $t$ was decomposed by the difference of each factor, as shown in equation (3):

$$
\triangle B I O_{t}=\Delta P O P_{t}+\Delta\left(\frac{V A A g r_{t}}{P O P_{t}}\right)+\Delta\left(\frac{B I O_{t}}{V A A g r_{t}}\right)
$$

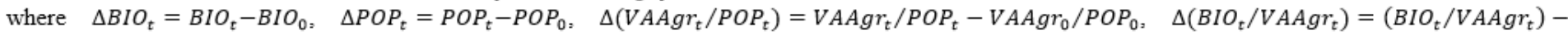
$\left(B I O_{0} /\right.$ VAAgr $\left._{0}\right)$.

In this study, the biomass domestic extraction was evaluated considering traditional land-use sectors: crop and animal production, hunting and related service activities (A01), forestry and logging (A02), and fishing and aquaculture (A03). The economic indicator as value added in agriculture was also evaluated considering to the same sectors. In this paper, all EU-28 countries were analyzed. The time period of 20002018 was defined as the scope of the bioeconomy. In parallel decomposition analysis was performed dividing this period into: 2000-2007 - growth period (period of economic growth and before bioeconomy strategy preparation), 2008-2012 - transition period (the period of bioeconomy strategy preparation) and 2013-2018 - strategy period (the period after bioeconomy strategy implementation and until its renewal).

\section{Results And Discussion}

\subsection{Changes in domestic extraction of biomass and main determinants in all analyzed periods}


Results from the additive decomposition analysis in Fig. 1 show that biomass domestic extraction (BIO) in EU-28 countries was fluctuating, but with a growing tendency and increase of 136.8 thousand tonnes or $8.2 \%$ from 2000 to 2018 . The main driving forces are population (POP) which increased by $5.2 \%$ and value added in agriculture sector per capita (VAAgr/POP) which increased by $4.6 \%$. Meanwhile intensity of bioresources (BIO/VAAgr) at the analysed period decreased by $1.6 \%$. The reduction of intensity level or growth of biomass productivity was positive tendency. However, in EU-28 the extraction of biomass increased because the growth of biomass productivity level was too slow, and it did not offset the driving forces.

Considering separate EU countries, Table 1 showed that changes in biomass extraction and driving forces between 2000 and 2018 vary among the EU28 countries. The growth of biomass extraction was observed in 20, while a reduction was observed in 8 countries. The obtained results demonstrated that the biggest growth of biomass extraction was in Bulgaria (80.5\%), Croatia (62.4\%) and Romania (60.6\%). These countries are the newest EU members and the bioeconomy strategy still is under development stage. Applying the multiplicative decomposition analysis, the main driver for growth of biomass extraction in Bulgaria and Croatia was the intensity of bioresources which increased by $116.3 \%$ and $88.9 \%$ respectively during the analyzed period. In Luxemburg, Germany, Estonia the intensity level of bioresource also increased in high rate. However, the reduction of value added, or population determined that the changes in biomass extraction was negligible in these countries. These tendencies from the perspective of sustainable bioeconomy is not favorable and countries should seek the solutions how to enhance productivity level of biomass. In Romania the main determinant of the growth of the biomass extraction was value added in agriculture sector per capita which increased by $70.3 \%$, while intensity of bioresources growth by $8.4 \%$. Therefore, in Romania the bioeconomy sector is extensively developed but productivity level still did not offset the growth of bioeconomy. 
Table 1

Changes in biomass domestic extraction and driving forces from 2000 to 2018

\begin{tabular}{|lllll|}
\hline & $B I O$ & $P O P$ & VAAgr/POP & BIO/VAAgr \\
\hline Belgium & 0.97 & 1.11 & 0.91 & 0.97 \\
\hline Bulgaria & 1.81 & 0.86 & 0.97 & 2.16 \\
\hline Czechia & 1.10 & 1.03 & 1.05 & 1.01 \\
\hline Denmark & 0.93 & 1.08 & 0.83 & 1.04 \\
\hline Germany & 1.16 & 1.01 & 0.85 & 1.36 \\
\hline Estonia & 1.12 & 0.94 & 0.91 & 1.31 \\
\hline Ireland & 0.99 & 1.28 & 0.86 & 0.90 \\
\hline Greece & 0.65 & 1.00 & 0.92 & 0.71 \\
\hline Spain & 1.04 & 1.15 & 1.06 & 0.85 \\
\hline France & 1.01 & 1.11 & 1.02 & 0.90 \\
\hline Croatia & 1.62 & 0.91 & 0.94 & 1.89 \\
\hline Italy & 0.70 & 1.06 & 0.91 & 0.72 \\
\hline Cyprus & 0.84 & 1.25 & 0.50 & 1.34 \\
\hline Latvia & 1.09 & 0.81 & 1.75 & 0.77 \\
\hline Lithuania & 1.38 & 0.80 & 1.35 & 1.28 \\
\hline Luxembourg & 1.13 & 1.39 & 0.23 & 3.59 \\
\hline Hungary & 1.30 & 0.96 & 1.50 & 0.90 \\
\hline Malta & 0.83 & 1.22 & 1.03 & 0.66 \\
\hline Netherlands & 1.11 & 1.08 & 1.13 & 0.91 \\
\hline Austria & 1.19 & 1.10 & 1.13 & 0.96 \\
\hline Poland & 1.25 & 0.99 & 1.13 & 1.11 \\
\hline Portugal & 1.04 & 1.00 & 1.06 & 0.97 \\
\hline Romania & 1.61 & 0.87 & 1.70 & 1.08 \\
\hline Slovenia & 1.21 & 1.04 & 1.27 & 0.92 \\
\hline Slovakia & 1.30 & 1.01 & 4.41 & 0.29 \\
\hline Finland & 1.13 & 1.07 & 1.21 & 0.88 \\
\hline
\end{tabular}




\begin{tabular}{|lllll|}
\hline & BIO & POP & VAAgr/POP & BIO/VAAgr \\
\hline Sweden & 1.16 & 1.14 & 1.17 & 0.87 \\
\hline United Kingdom & 0.98 & 1.13 & 0.98 & 0.89 \\
\hline
\end{tabular}

The biggest reduction of domestic biomass extraction in the analyzed period was observed in Greece (35.4\%) and Italy (30.1\%). In both cases, the main driver was a decrease of intensity of biomass. In Greece, it accounted for $29.4 \%$, and in Italy, it was $27.9 \%$. Furthermore, in these countries, the value added in the agriculture sector also decreased. Therefore, the issue in these countries still exists of whether the extensive bioeconomy sector development will maintain the high productivity level of biomass in order to stabilize the changes in biomass extraction. In Belgium, Ireland and the United Kingdom, the extraction of biomass decreased due to the same reasons: a reduction of value added and intensity level of bioresource. In Denmark and Cyprus, the extraction of biomass decreased only due to the reduction of value added in agriculture sector and developing the bioeconomy sector the biomass extraction can increase in very high rate due to ineffective agriculture sector. Meanwhile, only in Malta did the biomass productivity level offset the growth of agriculture and population and this country the most successfully implemented the sustainable bioeconomy strategy principles during all analyzed period. Furthermore, in Slovakia, the intensity level of biomass decreased the most - by $71 \%$, which slowdown the growth of biomass extraction whereas the economic growth in agriculture sector increased more than 4 times. This case reveals how important is productivity level particularly when the bioeconomy sector is developed very extensively.

\subsection{Changes in domestic extraction of biomass and main determinants in the economic growth period (2000-2007)}

After the Russian financial crisis, which affected EU countries, fast economic growth was observed in all EU countries. During this period, the bioeconomy sector was not highlighted, but agriculture and the growth of this sector played a serious role. Analyzing the changes in biomass extraction and its determinants between 2000 and 2007 among all EU28 countries, the average decrease of domestic biomass extraction was observed and accounted for $2.1 \%$. According to separate EU countries, in 17 countries, the reduction of biomass extraction occurred, while increase was observed in 11 countries. In Croatia, the growth of biomass extraction was the highest and both intensity of bioresources $(+21.2 \%)$ and value added in agriculture sector per capita (+16.2\%) were the main determinants of this growth. In Slovakia and Sweden, the biomass extraction increased in high rate as well by $17 \%$ and $16 \%$ respectively. Despite that in these countries the productivity level of biomass increased but it did not offset the fast growth of bioeconomy sector. 
Table 2

Changes in biomass domestic extraction and driving forces from 2000 to 2007

\begin{tabular}{|lllll|}
\hline & $B I O$ & $P O P$ & VAAgr/POP & BIO/VAAgr \\
\hline Belgium & 0.99 & 1.03 & 1.09 & 0.88 \\
\hline Bulgaria & 0.87 & 0.92 & 0.77 & 1.22 \\
\hline Czechia & 1.03 & 1.00 & 0.88 & 1.18 \\
\hline Denmark & 0.89 & 1.02 & 1.04 & 0.84 \\
\hline Germany & 1.07 & 1.00 & 1.08 & 0.98 \\
\hline Estonia & 0.65 & 0.96 & 1.49 & 0.46 \\
\hline Ireland & 0.90 & 1.15 & 0.69 & 1.14 \\
\hline Greece & 0.76 & 1.02 & 0.75 & 0.98 \\
\hline Spain & 0.96 & 1.11 & 0.94 & 0.93 \\
\hline France & 0.96 & 1.05 & 0.94 & 0.97 \\
\hline Croatia & 1.35 & 0.96 & 1.16 & 1.21 \\
\hline Italy & 0.88 & 1.02 & 0.92 & 0.94 \\
\hline Cyprus & 1.01 & 1.10 & 0.74 & 1.24 \\
\hline Latvia & 0.96 & 0.93 & 1.43 & 0.72 \\
\hline Lithuania & 1.13 & 0.93 & 1.11 & 1.09 \\
\hline Luxembourg & 1.10 & 1.10 & 0.46 & 2.19 \\
\hline Hungary & 0.99 & 0.98 & 1.05 & 0.96 \\
\hline Malta & 0.91 & 1.04 & 1.46 & 0.60 \\
\hline Netherlands & 0.96 & 1.03 & 1.04 & 0.89 \\
\hline Austria & 1.18 & 1.04 & 1.05 & 1.08 \\
\hline Poland & 1.05 & 1.00 & 1.21 & 0.87 \\
\hline Portugal & 0.92 & 1.03 & 0.95 & 0.94 \\
\hline Romania & 0.87 & 0.94 & 1.01 & 0.92 \\
\hline Slovenia & 0.96 & 1.01 & 1.08 & 0.88 \\
\hline Slovakia & 1.17 & 1.00 & 2.44 & 0.48 \\
\hline Finland & 1.05 & 1.02 & 1.05 & 0.98 \\
\hline
\end{tabular}




\begin{tabular}{|lllll|}
\hline & BIO & POP & VAAgr/POP & BIO/VAAgr \\
\hline Sweden & 1.16 & 1.03 & 1.26 & 0.90 \\
\hline United Kingdom & 0.88 & 1.04 & 0.93 & 0.91 \\
\hline
\end{tabular}

Meanwhile, in Greece (-24.4\%) and Estonia (-34.8\%) the biggest reduction of biomass extraction was observed. In the case of Greece, value added in the agriculture sector per capita was the significant negative driver for the decrease of biomass extraction, and it decreased by $25.0 \%$. Two determinants were significant for Estonia, but their influence was the opposite. The value added in the agriculture sector per capita had a positive effect on extraction of biomass changes (+48.7\%). Then, the intensity of bioresources had a negative effect on extraction of biomass changes, and it decreased by $54.2 \%$ in this period. Therefore, in Estonia during this period, the principles of a sustainable bioeconomy were implemented the most successfully. In Belgium, Denmark, Latvia, Hungary, Malta, the Netherlands, Poland and Slovenia, the productivity level also offset the increase of the agriculture sector.

\subsection{Changes in domestic extraction of biomass and main determinants in the transition period (2008-2012)}

The period of 2008-2012 was considered as bioeconomy strategy preparation also this period encompassed the economic crisis and recovery. Results of changes in extraction of biomass and determinants between 2008 and 2012 among the EU28 countries was shown in Table 3. Therefore, in this period, domestic extraction of biomass in all EU28 countries was almost stable and accounted for $0.4 \%$. The reduction of biomass extraction was observed in 17 countries, while an increase was observed in 11 countries. Comparing with 2000-2007 period in different EU countries the biggest growth of extraction occurred. In transition period in Cyprus, Estonia and Latvia the biomass extractions increased the most by $48.9 \%, 32 \%$ and $28.8 \%$ respectively. Despite that during the economic growth period Estonia was of one of example, while in this period the intensity level increased the most and it determined the increase in biomass extraction. In Cyprus and Latvia, the growth of intensity levels also contributed to the increase in the resource extraction, intensity of biomass increased by $50.6 \%$ and $22.5 \%$ respectively. In Lithuania, the growth of extraction was also high - by $18 \%$. However, in this country, the growth of value added in agriculture sector determined this change the most. Furthermore, among EU countries the biggest level of agriculture sector growth was observed in Lithuania and in Denmark. But in Denmark the increase of extraction slow downed one of the biggest declines of biomass intensity level. 
Table 3

Changes in biomass domestic extraction and driving forces from 2008 to 2012

\begin{tabular}{|lllll|}
\hline & $B I O$ & $P O P$ & VAAgr/POP & BIO/VAAgr \\
\hline Belgium & 0.94 & 1.04 & 1.02 & 0.88 \\
\hline Bulgaria & 0.98 & 0.97 & 0.78 & 1.30 \\
\hline Czechia & 0.96 & 1.02 & 1.01 & 0.93 \\
\hline Denmark & 1.05 & 1.02 & 1.23 & 0.84 \\
\hline Germany & 1.07 & 0.98 & 0.86 & 1.27 \\
\hline Estonia & 1.32 & 0.99 & 0.99 & 1.35 \\
\hline Ireland & 0.95 & 1.03 & 0.92 & 1.00 \\
\hline Greece & 0.96 & 1.00 & 1.19 & 0.80 \\
\hline Spain & 0.86 & 1.03 & 0.92 & 0.91 \\
\hline France & 0.97 & 1.02 & 0.96 & 0.99 \\
\hline Croatia & 0.80 & 0.99 & 0.71 & 1.14 \\
\hline Italy & 0.89 & 1.01 & 0.98 & 0.89 \\
\hline Cyprus & 1.49 & 1.11 & 0.89 & 1.51 \\
\hline Latvia & 1.29 & 0.93 & 1.13 & 1.22 \\
\hline Lithuania & 1.18 & 0.93 & 1.21 & 1.04 \\
\hline Luxembourg & 1.02 & 1.08 & 1.08 & 0.87 \\
\hline Hungary & 0.70 & 0.99 & 0.63 & 1.12 \\
\hline Malta & 0.93 & 1.02 & 1.09 & 0.83 \\
\hline Netherlands & 0.99 & 1.02 & 1.00 & 0.97 \\
\hline Austria & 0.87 & 1.01 & 0.93 & 0.92 \\
\hline Poland & 1.05 & 1.00 & 1.03 & 1.02 \\
\hline Portugal & 1.05 & 1.00 & 0.98 & 1.07 \\
\hline Romania & 0.90 & 0.97 & 0.80 & 1.17 \\
\hline Slovenia & 1.03 & 1.02 & 0.89 & 1.13 \\
\hline Slovakia & 0.85 & 1.01 & 1.03 & 0.83 \\
\hline Finland & 0.99 & 1.02 & 1.03 & 0.95 \\
\hline
\end{tabular}




\begin{tabular}{|lllll|}
\hline & BIO & POP & VAAgr/POP & BIO/VAAgr \\
\hline Sweden & 1.03 & 1.03 & 1.00 & 0.99 \\
\hline United Kingdom & 0.93 & 1.03 & 0.93 & 0.97 \\
\hline
\end{tabular}

The biggest reduction of biomass occurred in Croatia (-19.9\%), and Hungary (-29.7\%). In the period of economic growth, the biomass extraction increased the most in Croatia. In this period in both Croatia and Hungary value added in agriculture sector per capita was the main driver for negative changes in biomass extraction, however the intensity level increased. Therefore, how important is the biomass productivity level seeking that the growth of bioeconomy sector did not cause huge growth of biomass extraction which could exceed the biomass capacity. Meanwhile in other countries as Belgium, Czechia, Denmark, Greece, Luxemburg, Malta, the Netherlands, Slovakia and Finland, the reduction of biomass intensity offset the population and economic growth and, in these countries, the negligible reduction of biomass extraction was observed. Therefore, before the launched of bioeconomy strategy the principle of sustainable bioeconomy in latter countries was successfully implemented.

\subsection{Changes in domestic extraction of biomass and main determinants in strategy period (2013-2018)}

During the period when EU bioeconomy strategy was launched and implemented from the 2013 to 2018, the average increase of domestic extraction of biomass in all EU28 countries was the highest comparing all analyzed periods and reached $7.6 \%$. Therefore, generally in EU the development of bioeconomy was related to increase in bioresource production, export and consumption. However, the main principle remains that the production and consumption of biomass would be more efficient. Considering separate countries, the growth of biomass extraction was observed in almost all EU countries - 22, while decrease occurred only in 6 countries. The biggest growth in extraction level was in Slovenia, Estonia and Romania, respectively, by $25.4 \%, 24.1 \%$ and $21.4 \%$. Value added in agriculture sector per capita was the main driver for growth of biomass extraction in Slovenia (33.1\%) and Romania (25.1\%). In Estonia despite the sharp decline of value added in agriculture sector (by $-36.8 \%$ ), increase of intensity of bioresources by $96.4 \%$ determined the growth of biomass extraction. Therefore, during these two periods (transition and strategy) the sustainable bioeconomy principles was the worst implemented in Estonia. Liobikiene at al (2019) found that Estonia almost achieved the level of land biocapacity. The highest intensity growth was observed in Poland and Germany as well, and these tendencies are not favorable, considering sustainable bioeconomy principles. Particular Germany where the sustainable aspect was highlighted when the bioeconomy strategy was launched. The growth of biomass extraction was negligible in Germany only due to the reduction of bioeconomy sector. 
Table 4

Changes in biomass domestic extraction and driving forces from 2013 to 2018

\begin{tabular}{|lllll|}
\hline & $B I O$ & $P O P$ & VAAgr/POP & BIO/VAAgr \\
\hline Belgium & 0.99 & 1.02 & 0.96 & 1.01 \\
\hline Bulgaria & 1.07 & 0.97 & 1.17 & 0.95 \\
\hline Czechia & 1.03 & 1.01 & 1.19 & 0.86 \\
\hline Denmark & 0.99 & 1.03 & 0.91 & 1.06 \\
\hline Germany & 1.09 & 1.03 & 0.75 & 1.42 \\
\hline Estonia & 1.24 & 1.00 & 0.63 & 1.96 \\
\hline Ireland & 1.04 & 1.05 & 1.30 & 0.76 \\
\hline Greece & 0.94 & 0.98 & 1.08 & 0.89 \\
\hline Spain & 1.07 & 1.00 & 1.12 & 0.95 \\
\hline France & 1.08 & 1.02 & 1.11 & 0.95 \\
\hline Croatia & 1.06 & 0.96 & 1.01 & 1.09 \\
\hline Italy & 0.90 & 1.01 & 0.99 & 0.89 \\
\hline Cyprus & 1.00 & 1.00 & 0.90 & 1.12 \\
\hline Latvia & 1.10 & 0.96 & 1.09 & 1.06 \\
\hline Lithuania & 0.89 & 0.95 & 0.99 & 0.95 \\
\hline Luxembourg & 1.07 & 1.12 & 0.89 & 1.07 \\
\hline Hungary & 1.10 & 0.99 & 1.27 & 0.88 \\
\hline Malta & 0.88 & 1.13 & 1.03 & 0.76 \\
\hline Netherlands & 1.14 & 1.02 & 1.06 & 1.05 \\
\hline Austria & 1.10 & 1.04 & 1.12 & 0.94 \\
\hline Poland & 1.17 & 1.00 & 0.86 & 1.36 \\
\hline Portugal & 1.06 & 0.98 & 1.07 & 1.01 \\
\hline Romania & 1.21 & 0.98 & 1.25 & 0.99 \\
\hline Slovenia & 1.25 & 1.00 & 1.33 & 0.94 \\
\hline Slovakia & 1.08 & 1.01 & 1.16 & 0.93 \\
\hline Finland & 1.02 & 1.11 & 0.94 \\
\hline
\end{tabular}




\begin{tabular}{|lllll|}
\hline & BIO & POP & VAAgr/POP & BIO/VAAgr \\
\hline Sweden & 1.01 & 1.06 & 0.97 & 0.99 \\
\hline United Kingdom & 1.09 & 1.04 & 1.06 & 0.99 \\
\hline
\end{tabular}

In Belgium, Denmark, Greece, Italy, Lithuania and Malta, biomass extraction decreased. In Italy (-10.3\%), Lithuania $(-11.1 \%)$, and Malta $(-11.6 \%)$ the reduction was the highest. The intensity of bioresources was the main driver for Italy and Malta. In Malta, intensity of biomass decreased by $24.0 \%$ and in Italy decrease by $10.5 \%$. In Lithuania, there were two negative significant drivers: decrease of population by $5.5 \%$ and decrease of intensity of bioresources by $5.0 \%$. From all these countries, only Italy has launched the national bioeconomy strategy. Meanwhile, considering other EU countries which have a national bioeconomy strategy, in almost all countries, the intensity of biomass decreased (expect Germany, Latvia and the Netherlands), but it did not offset the other driving forces and biomass extraction increased. Therefore, the growth of productivity level is very important, but it is essential to maintain the stabilization of biomass increase particularly considering that these countries could very quickly exceed the land biocapacity (Liobikiene et al., 2019). Among EU countries only in Greece, Italy and Malta the productivity level offset the driving forces and biomass extraction decreased. Therefore, these countries should further follow the positive tendencies of bioeconomy strategy implementation. Bioeconomy strategies implementation in EU countries can help to address the dilemma of meeting increasing demands for goods and services of a growing and more wealthy population, while at the same time halting the overexploitation of resources and degradation of ecosystems and biodiversity and also mitigating climate change.

In the literature, both implementing sustainable or circular economy authors provided vast recommendations as potential feedstock for a generation of bio-based products to use food waste or other wastes generated in agriculture sector (Dahiya et al., 2018; Maina, et al., 2017; Mohan et al., 2018; Singh et al., 2021; Bužinskienè and Miceikienè, 2021). The global innovation, technologies and investments in agriculture are also crucial in seeking to enhance the bioresource productivity level (Liobikiene et al., 2019; Wohlgemith et al., 2021). The public acceptance of implementing tools and sustainable use of bioresources is important as well (Woźniak et al., 2021).

Many countries are developing and implementing bioeconomy strategies. While the original emphasis of most of these strategies was on climate protection and on reducing dependency on fossil resources, other sustainability dimensions need to be addressed as well, in particular those spelled out by the Sustainable Development Goals. Therefore, bioeconomy transitions have become integral part of an overall sustainability transition. This requires improvements on the consumption and production side, to avoid excessive demands on bioresources as a result of bioeconomy transitions and the substitution of fossil resources (Hoff et al., 2018).

\section{Conclusions}


A sustainable bioeconomy covers the efficient production of feed, food, biobased products and bioenergy products using renewable biological resources. Therefore, implementing sustainable bioeconomy requires improvement in the productivity of the bioresources, which is included almost in all national bioeconomy strategies. The enhancement of biomass productivity is important; however, it is more important to stabilize the growth of biomass which in EU countries is limited. Therefore, the aim of this paper is to reveal how productivity (or conversely intensity) level contributes to the changes in biomass extraction in all EU countries. In order to reveal whether the changes in productivity level offsets the changes in driving forces as population and economy activities the IPAT approach was applied. The time period of 2000-2018 was defined as the scope of the bioeconomy. In parallel decomposition analysis was performed dividing this period into 2000-2007 - growth period, 2008-2012 - transition period and 2013-2018 - strategy period.

The results showed that in separate EU countries and analyzed periods, the changes in biomass extraction were different. During the period of economic growth and transition, biomass extraction decreased in more than half of all EU countries. The decline of value added in the agriculture sector and/or reduction in biomass intensity level were the main determinants of these changes. Meanwhile, during the bioeconomy strategy period (2013-2018), the reduction of biomass extractions was observed in only 6 EU countries. Encompassing all analyzed periods (2000-2018) the growth of biomass extraction was observed in 20 , while the reduction was observed in 8 countries. The main driving forces as population in EU-28 increased by $5.2 \%$ and value added in agriculture sector per capita increased by $4.6 \%$. However, in EU-28 the extraction of biomass increased because that the reduction of biomass intensity level was too slow (1.6\%), and it did not offset the driving forces.

Focusing on strategy period (2013-2018) only in Greece, Italy and Malta the productivity level of biomass offset the driving forces - economic and population growth. Meanwhile in Estonia, Germany and Poland despite the reduction of value added in agriculture sector the growth of intensity level of biomass determined the increase in extraction of biomass. Therefore, this study showed that achievement of sustainable bioeconomy principles in major of EU countries remains a great challenge.

\section{Declarations}

Ethical Approval: Not applicable;

Consent to Participate: Not applicable;

Consent to Publication: Not applicable;

Authors Contributions: Genovaitė Liobikienė, Ričardas Krikštolaitis and Astrida Miceikienè equally contributed to preparation of paper;

Funding: Not applicable;

Competing Interests: Not applicable; 
Availability of data and materials: Not applicable.

\section{References}

1. Angouria-Tsorochidou E, Teigiserova DA, Thomsen M (2021) Limits to circular bioeconomy in the transition towards decentralized biowaste management systems. Resources, Conservation and Recycling, 164, 105207

2. Antar M, Lyu D, Nazari M, Shah A, Zhou X, Smith DL (2021) Biomass for a sustainable bioeconomy: An overview of world biomass production and utilization. Renew Sustain Energy Rev 139:110691

3. Asada R, Stern T (2018) Competitive bioeconomy? Comparing bio-based and non-bio-based primary sectors of the world. Ecol Econ 149:120-128

4. Baninla Y, Lu Y, Zhang Q, Omotehinse AO, Zheng X, Zhang M, Khan K (2020) Material use and resource efficiency of African sub-regions. J Clean Prod 247:119092

5. Banja M, Jégard M, Motola V, Sikkema R (2019a) Support for biogas in the EU electricity sector-A comparative analysis. Biomass Bioenerg 128:105313

6. Banja M, Sikkema R, Jégard M, Motola V, Dallemand JF (2019b) Biomass for energy in the EU-The support framework. Energy Policy 131:215-228

7. Bell J, Paula L, Dodd T, Németh S, Nanou Ch, Mega V, Campos P (2018) EU ambition to build the world's leading bioeconomy-Uncertain times demand innovative and sustainable solutions. New Biotechnol 40:25-30

8. Blumberga D, Indzere Z, Muizniece I, Blumberga A, Bazbauers G, Gravelsins A (2017) Why Bioeconomy is Actual for Latvia. Research Achievements in Institute of Energy Systems Environment Energy Procedia 113:460-465

9. Bórawski P, Bełdycka-Bórawska A, Szymańska EJ, Jankowski KJ, Dubis B, Dunn JW (2019) Development of renewable energy sources market and biofuels in The European Union. Journal of cleaner production 228:467-484

10. Brizga J, Miceikienè A, Liobikienè G (2019) Environmental aspects of the implementation of bioeconomy in the Baltic Sea Region: An input-output approach. J Clean Prod 240:118238

11. Bužinskienè R, Miceikienè A (2021) Assessment of biomass utilization for energy production from agricultural residue. Management Theory Studies for Rural Business Infrastructure Development 42(4):549-560

12. Calicioglu Ö, And Bogdanski A (2021) Linking the bioeconomy to the 2030 sustainable development agenda: Can SDG indicators be used to monitor progress towards a sustainable bioeconomy? New Biotechnology, 61, 40-49

13. Chiu AS, Dong L, Geng Y, Rapera C, Tan E (2017) Philippine resource efficiency in Asian context: Status, trends and driving forces of Philippine material flows from 1980 to 2008. J Clean Prod 153:63-73 
14. Communication from the Commission to the European Parliament, the European Council, the Council, the European Economic and Social Committee and the Committee of the Regions the European Green Deal (2019) https://eur-lex.europa.eu/legal-content/LT/TXT/PDF/? uri $=$ CELEX:52019DC0640\&from $=E N$

15. Cristóbal J, Matos CT, Aurambout J-P, Manfredi S, Kavalov B (2016) Environmental sustainability assessment of bioeconomy value chains. Biomass Bioenerg 89:159-171

16. Dahiya S, Kumar AN, Sravan JS, Chatterjee S, Sarkar O, Mohan SV (2018) Food waste biorefinery: Sustainable strategy for circular bioeconomy. Bioresour Technol 248:2-12

17. Devaney L, Henchion M (2018) Consensus, caveats and conditions: International learnings for bioeconomy: development. J Clean Prod 174:1400-1411

18. Dong L, Dai M, Liang H, Zhang N, Mancheri N, Ren J, ... Hu M (2017) Material flows and resource productivity in China, South Korea and Japan from 1970 to 2008: A transitional perspective. J Clean Prod 141:1164-1177

19. Egelyng H, Romsdal A, Hansen HO, Slizyte R, Carvajal AK, Jouvenot L, Hebrok M, Honkapää K, Wold JP, Seljasen R, Aursand M (2018) Cascading Norwegian Co-streams for bioeconomic transition. J Clean Prod 172:3864-3873

20. Egenolf V, Bringezu S (2019) Conceptualization of an Indicator System for Assessing the Sustainability of the Bioeconomy. Sustainability 11(2):443

21. El-Chichakli B, von Braun J, Lang C, Barben D, Philp J (2016) Policy: Five cornerstones of a global bioeconomy. Nature News 535(7611):221

22. EU (2012) Innovating for Sustainable Growth: A Bioeconomy for Europe. Communication from the Commission to the European Parliament, theEuropean Economic and Social Committee and the Committee of the Regions. http://ec.europa.eu/research/bioeconomy/pdf/official-strategy en.pdf

23. EU (2018) A sustainable Bioeconomy for Europe: strengthening the connection between economy, society and the environment. Updated Bioeconomy Strategy. https://ec. europa. eu/research/bioeconomy/

24. European Bioeconomy, Panel (2014) In:. 2nd Plenary Meeting, $12 \mathrm{e} 13$ February 2014. Summary of Discussions

25. Fishman T, Schandl H, Tanikawa $H$ (2015) The socio-economic drivers of material stock accumulation in Japan's prefectures. Ecol Econ 113:76-84

26. Fuentes-Saguar PD, Mainar-Causapé AJ, Ferrari E (2017) The role of bioeconomy sectors and natural resources in EU economies: A social accounting matrix-based analysis approach. Sustainability $9(12): 2383$

27. Giampietro M (2019) On the circular bioeconomy and decoupling: implications for sustainable growth. Ecological economics 162:143-156

28. Hamelin L, Borzęcka M, Kozak M, Pudełko R (2019) A spatial approach to bioeconomy: Quantifying the residual biomass potential in the EU-27. Renew Sustain Energy Rev 100:127-142 
29. Hansen L, Bjørkhaug B (2017) Visions and Expectations for the Norwegian Bioeconomy. Sustainability 9(3):341

30. Heimann T (2019) Bioeconomy and SDGs: Does the bioeconomy support the achievement of the SDGs? Earths Future 7(1):43-57

31. Hoff H, Johnson FX, Allen B, Biber-Freudenberger L, Förster. J.J (2018) Sustainable bio-resource pathways towards a fossil-free world: the European bioeconomy in a global development context, Policy Paper produced for the IEEP Think2030 conference, Brussels, October 2018

32. Huang C, Han J, Chen WQ (2017) Changing patterns and determinants of infrastructures' material stocks in Chinese cities. Resour Conserv Recycl 123:47-53

33. Juerges N, Hansjürgens $B$ (2018) Soil governance in the transition towards a sustainable bioeconomy - A review. J Clean Prod 170:1628-1639

34. Kalt G, Baumann M, Lauk CH, Kastner T, Kranzl L, Schipfer F, Lexer M, Rammer W, Schaumberger A, Schriefl E (2016) Transformation scenarios towards a low-carbon bioeconomy in Austria. Energy Strategy Reviews 13-14:125-133

35. Kardung M, Cingiz K, Costenoble O, Delahaye R, Heijman W, Lovrić M, Zhu BX (2021) Development of the Circular Bioeconomy: Drivers and Indicators. Sustainability 13(1):413

36. Koukios E, Monteleone M, Carrondo MJT, Charalambous A, Girio F, Hernández EL, Mannelli S, Parajó JC, Polycarpou P, Zabaniotou A (2018) Targeting sustainable bioeconomy: A new development strategy for Southern European countries. The Manifesto of the European Mezzogiorno. J Clean Prod 172:3931-3941

37. Liobikienè G, Baležentis T, Štreimikienè D, Chen X (2019) Evaluation of bioeconomy in the context of strong sustainability. Sustain Dev 27(5):955-964

38. Liobikienè G, Baležentis T, Štreimikienè D, Chen X (2020) The trends in bioeconomy development in the European Union: Exploiting capacity and productivity measures based on the land footprint approach. Land Use Policy 91:104375

39. Maina S, Kachrimanidou V, Koutinas A (2017) A roadmap towards a circular and sustainable bioeconomy through waste valorization. Current Opinion in Green Sustainable Chemistry 8:18-23

40. Mohan SV, Dahiya S, Amulya K, Katakojwala R, Vanitha TK (2019) Can circular bioeconomy be fueled by waste biorefineries-A closer look. Bioresource Technology Reports 7:100277

41. Mohan SV, Nikhil GN, Chiranjeevi P, Reddy CN, Rohit MV, Kumar AN, Sarkar O (2016) Waste biorefinery models towards sustainable circular bioeconomy: critical review and future perspectives. Bioresour Technol 215:2-12

42. Mola-Yudego B, Arevalo J, Díaz-Yáñez O, Dimitriou I, Freshwater E, Haapala A, Selkimäki M (2017) Reviewing wood biomass potentials for energy in Europe: the role of forests and fast growing plantations. Biofuels 8(4):401-410

43. Muizniece I, Timma L, Blumberga A, Blumberga D (2016) The methodology for assessment of bioeconomy efficiency. Energy Procedia 95:482-486 
44. Pfau SF, Hagens JE, Dankbaar B, Smits AJM (2014) Visions of sustainability in bioeconomy research. Sustainability 6:1222-1249

45. Philippidis G, Sanjuán-López Al (2018) A re-examination of the structural diversity of biobased activities and regions across the EU. Sustainability 10(11):4325

46. Piotrowski et al (2015) as cited in Standing Committee on Agricultural Research. Sustainable agriculture, forestry and fisheries in the bioeconomy; A challenge for Europe; 4th SCAR foresight exercise, Brussels, European Commission Publications Office. 34-25

47. Ramcilovic-Suominen S, Pülzl H (2018) Sustainable development-a 'selling point'of the emerging EU bioeconomy policy framework? Journal of cleaner production 172:4170-4180

48. Román-Collado R, Cansino JM, Botia C (2018) How far is Colombia from decoupling? Two-level decomposition analysis of energy consumption changes. Energy 148:687-700

49. Ronzon T, M'Barek R (2018) Socioeconomic indicators to monitor the EU's bioeconomy in transition. Sustainability 10(6):1745

50. Ronzon T, Sanjuán Al (2020) Friends or foes? A compatibility assessment of bioeconomy-related Sustainable Development Goals for European policy coherence. J Clean Prod 254:119832

51. Rural Biomass Energy Book (2020) Cleaner Energy Better Environment Higher Rural Income People's Republic of China. - https://www.adb.org/sites/default/files/publication/27997/rural-biomassenergy-2020.pdf

52. Sadhukhan J et al (2018) Role of bioenergy, biorefinery and bioeconomy in sustainable development: Strategic pathways for Malaysia. Renew Sustain Energy Rev 81:1966-1987

53. Sasson A, Malpica C (2018) Bioeconomy in Latin America. New Biotechnol 40:40-45

54. Scarlat N, Dallemand JF, Fahl F (2018) Biogas: Developments and perspectives in Europe. Renewable Energy 129:457-472

55. Scarlat N, Dallemand J-F, Monforti-Ferrario F, Nita V (2015) The role of biomass and bioenergy in a future bioeconomy: policies and facts. Environmental Development 15:3-34

56. Scarlat N, Fahl F, Dallemand JF, Monforti F, Motola V (2018) A spatial analysis of biogas potential from manure in Europe. Renew Sustain Energy Rev 94:915-930

57. Schandl H, West J (2012) Material flows and material productivity in China, Australia, and Japan. J Ind Ecol 16(3):352-364

58. Scheiterle L, Ulmer A, Birner R, Pyka A (2018) From Commodity-Based Value Chains to BiomassBased Value Webs: the Case of Sugarcane in Brazil's Bioeconomy. J Clean Prod 172(20):3851-3863

59. Schipfer F, Kranzl L, Leclère D, Sylvain L, Forsell N, Valin H (2017) Advanced biomaterials scenarios for the EU28 up to 2050 and their respective biomass demand. Biomass Bioenerg 96:19-27

60. Schutte G (2018) What Kind of Innovation Policy does the Bioeconomy Need? New Biotechnology, $40,82-86$

61. Shah IH, Dong L, Park HS (2020) Characterization of resource consumption and efficiency trends in Bangladesh, India and Pakistan: Economy-wide biotic and abiotic material flow accounting from 
1978 to 2017. J Clean Prod 250:119554

62. Sharma P, Gaur VK, Sirohi R, Varjani S, Kim SH, Wong JW (2021) Sustainable processing of food waste for production of bio-based products for circular bioeconomy. Bioresource Technology, 124684

63. Singh A, Christensen T, Panoutsou C (2021) Policy review for biomass value chains in the European bioeconomy. Global Transitions 3:13-42

64. Stegmann P, Londo M, Junginger M (2020) The circular bioeconomy: Its elements and role in European bioeconomy clusters, 6. X, Resources, p 100029

65. Tian Y, Ruth M, Zhu D (2017) Using the IPAT identity and decoupling analysis to estimate water footprint variations for five major food crops in China from 1978 to 2010. Environ Dev Sustain 19(6):2355-2375

66. Urmetzer S, Lask J, Vargas-Carpintero R, Pyka A (2020) Learning to change: Transformative knowledge for building a sustainable bioeconomy. Ecol Econ 167:106435

67. Vainio A, Ovaska U, Varho V (2019) Not so sustainable? Images of bioeconomy by future environmental professionals and citizens. Journal of cleaner production 210:1396-1405

68. Wang H, Yue Q, Lu Z, Schuetz H, Bringezu S (2013) Total material requirement of growing China: 1995-2008. Resources 2(3):270-285

69. Wang PC, Lee YM, Chen CY (2014) Estimation of resource productivity and efficiency: An extended evaluation of sustainability related to material flow. Sustainability 6(9):6070-6087

70. Weinzettel J, Kovanda J (2011) Structural decomposition analysis of raw material consumption: the case of the Czech Republic. J Ind Ecol 15(6):893-907

71. West J, Schandl H (2013) Material use and material efficiency in Latin America and the Caribbean. Ecol Econ 94:19-27

72. Wietschel L, Thorenz A, Tuma A (2019) Spatially explicit forecast of feedstock potentials for second generation bioconversion industry from the EU agricultural sector until the year 2030. J Clean Prod 209:1533-1544

73. Wohlgemuth R, Twardowski T, Aguilar A (2021) Bioeconomy moving forward step by step-A global journey. New Biotechnol 61:22-28

74. Woźniak E, Tyczewska A, Twardowski T (2021) Bioeconomy development factors in the European Union and Poland. New Biotechnol 60:2-8

75. Wydra S, Hüsing B, Köhler J, Schwarz A, Schirrmeister E, Voglhuber-Slavinsky A (2021) Transition to the Bioeconomy-Analysis and scenarios for selected niches. Journal of Cleaner Production, 126092

76. Zabaniotou A (2018) Redesigning a Bioenergy Sector in EU in the Transition to Circular Waste-based Bioeconomy-A Multidisciplinary Review. J Clean Prod 177(10):197-206

77. Zeug W, Bezama A, Moesenfechtel U, Jähkel A, Thrän D (2019) Stakeholders' interests and perceptions of bioeconomy monitoring using a sustainable development goal framework. Sustainability 11(6):1511 
Figures

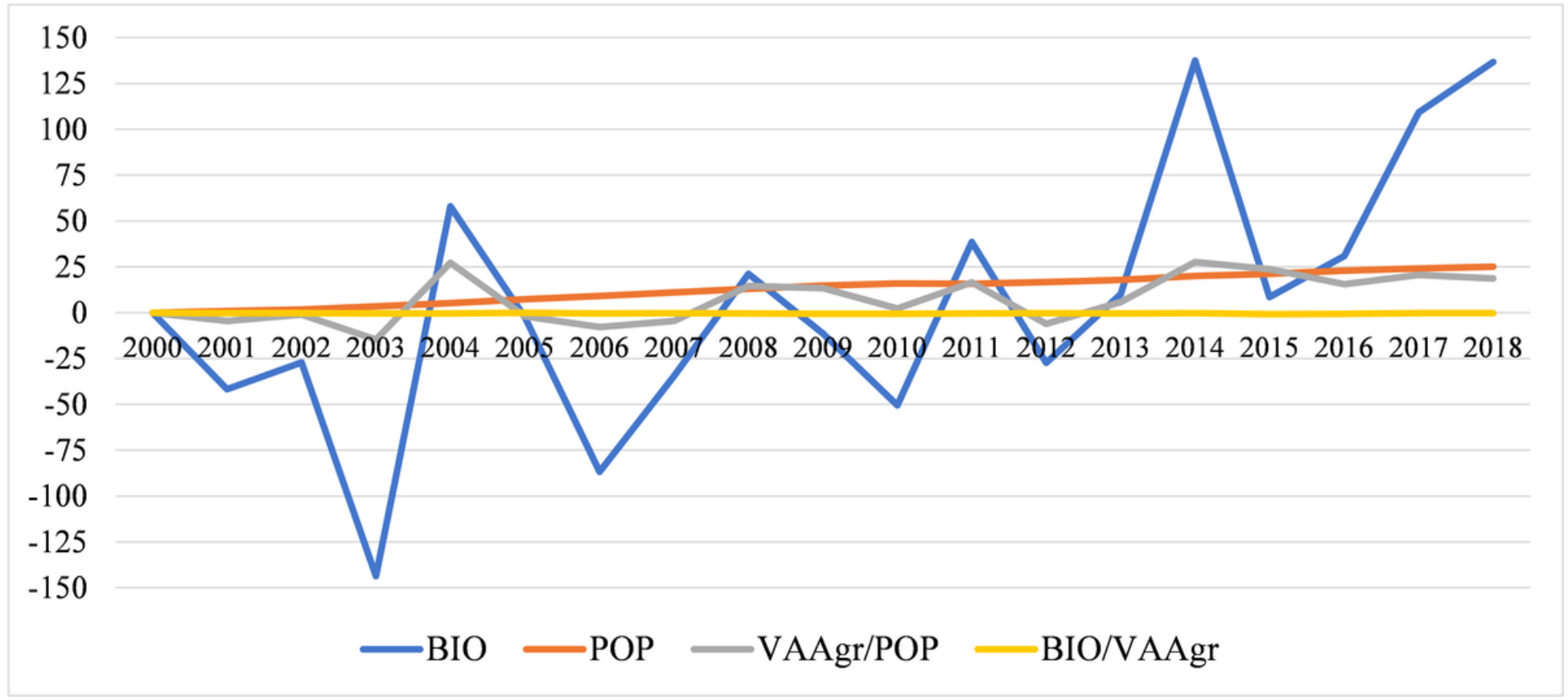

\section{Figure 1}

Additive decomposition analysis of biomass domestic extraction for the time period $2000-2018$ 